\title{
Industry, Management Capabilities and Firms' Competitiveness: An Empirical Contribution
}

\author{
Miguel Acosta Molina*, Idaira Barrios del Pino ${ }^{\dagger}$ and Alicia Correa Rodríguez \\ Departamento de Economía Financiera y Contabilidad, Facultad de Ciencias Económicas y Empresariales, Campus de \\ Guajara, Camino La Hornera, s/n. La Laguna, Santa Cruz de Tenerife 38071, Spain
}

\begin{abstract}
The aim of this paper is to contribute to the knowledge of strategic factors that explain the competitive position reached by firms in their activity sector.

We have used a survey carried out in 1999 on 287 executives that belong to the service sector in the province of Santa Cruz de Tenerife. We have analysed the differential factors that distinguish the strategic performance of competitive vis-à-vis non-competitive firms, by jointly assessing the variables representative of the sector (five competitive forces defined by Porter) and variables of an internal feature. Finally, we have moved the level of analysis from the industry to the firm; specifically, we have focused on managerial capabilities due to the significant role played by managers in the strategic decision-making process.

The use of cluster analysis to classify firms depending on their degree of competitiveness and the application of the See5 induction algorithm of rules and decision trees to determine the differential factors that distinguish competitive from non-competitive firms, provide a methodological framework for the most significant contributions of this work. Copyright (C) 2004 John Wiley \& Sons, Ltd.
\end{abstract}

\section{INTRODUCTION}

Throughout the 1980s, developments in the field of strategic management were almost exclusively based on the relationship between strategy and environment, and Porter's (1980) contributions were highly significant. Based on the structureconduct-performance paradigm of industrial organization (Mason, 1949; Bain, 1959), this approach affirms that the conditions of the industry

\footnotetext{
*Correspondence to: Departamento de Economía Financiera y Contabilidad, Facultad de Ciencias Económicas y Empresariales, Campus de Guajara, Camino La Hornera, s/n. La Laguna, Santa Cruz de Tenerife 38071, Spain.

E-mail:mmolin@ull.es

†ibarrios@ull.es

†alcorrea@ull.es
}

Copyright (C) 2004 John Wiley \& Sons, Ltd. wherein firms carry out their activity have a decisive influence on strategy formulation to achieve sustainable competitive advantages, thereby conditioning the firm's economic returns. ${ }^{1}$

Despite being well accepted, the nature of this model as a unique explanatory guide of the entrepreneurial competitiveness has been questioned, with the appearance of a wide range of empirical works. These works have demonstrated that the structural characteristics of industries only partly explain differences in entrepreneurial returns (Schmalensee, 1985; Cool and Schendel, 1988; Hansen and Wernerfelt, 1989; Rumelt, 1991; Montgomery and Wernerfelt, 1991), while establishing a greater difference in returns between firms of the same sector than between firms from 
different ones. These questions led to a reconsideration of the importance of firms' internal factors as the grounds for business strategy and the basis of competitive success (Resources based view- $R B V$-). ${ }^{2}$

On this line, RBV has defended the fact that developing and maintaining competitive advantages is based on possessing a series of internal factors which, as they are largely intangible, mostly explains a firm's superior returns in its activity sector (Rumelt and Wensley, 1980; Wernerfelt, 1984; Rumelt, 1984). These resources have been considered as strategic if they are also heterogeneous, rare, valuable, imperfectly imitable and non-substitutable (Barney, 1991; Grant, 1991; Peteraf, 1993).

In this sense, numerous studies have positively correlated the achievements of a firm possessing certain intangibles such as R+D (Hirschey, 1982; Lev and Zarowin, 1998), software capitalization (Aboody and Lev, 1998), advertising expenses (Bubblitz and Ettredge, 1989; Chauvin and Hirschey, 1993), brands (Smiddy, 1983; Kim and Chung, 1997), covenants not to compete (Russell, 1990), or human capital strategic management and their impact on the value of the firm (Wright et al., 1994; Truss and Gratton, 1994; Hand, 1998; Huselid, 1999).

However, despite the significant role played by managers in the strategic process (decisions about acquisition, development and deployment of organizational resources, the conversion of these resources into valuable products and the delivery of value to organizational stakeholders), this has not been sufficiently studied in the sphere of RBV. Faced with this circumstance, as explained by Castanias and Helfat (1991) and Lado et al. (1992), we understand that these can be potent sources of managerial rents and sustained competitive advantage.

Thus, for Ulrich and Lake (1990), the achievement of higher returns over a long period by the best-known organizations may be due to their managers' efficient decision-making processes, which enable them to develop sustained competitive advantages, in such a way that managers with superior human capital generate above-average firm performance (Castanias and Helfat, 2001). ${ }^{3}$

In this sense, Barney (1991) argues that 'Managers are important in this model, for it is managers that are able to understand and describe the economic performance potential of a firm's endowments. Without such managerial analyses, sustained competitive advantage is not likely'.

In line with this approach, therefore, the role of managerial capabilities is particularly significant. These are defined by Lado and Wilson (1994) as the unique capabilities of the organization's strategic leaders enabling them, firstly, to articulate a strategic vision and communicate it to the entire organization, providing its members with the power to carry it out (Wesley and Mintzberg, 1989) and, secondly, to foster a beneficial organization-environment relationship (Hambrick and Mason, 1984; Tushman and Romanelli, 1985). ${ }^{4}$

Finally, a manager's accurate perception of environmental structural conditions is a crucial first step towards correctly implementing strategies leading to business success in the long term (Day and Nedungadi, 1994). In this sense, Mahoney (1995) understands that the management team's attributes may satisfy conditions for achieving and maintaining competitive advantage. The management team is valuable when it exploits opportunities and/or neutralizes threats in a firm's environment.

These approaches seem to be in line with those of authors who consider the convergence of RBV towards a firm's internal factors to be excessive, as occurred in the 1980s with environmental conditions, which has led Barney (2001) to finally accept that 'A complete model of strategic advantage would require a full integration of models of the competitive environment with models of firm resources'.

However, a revision of the strategic literature reveals that this integrative focus is not entirely novel, since there is currently a significant body of works from both a theoretical and empirical perspective.

In the theoretical sphere, rooted in industrial organization and organizational theories, the main contributions have attempted to explain a firm's competitive position based on a set of factors and how they interrelate: business position, industry environment, strategy and structure (White and Hamermesh, 1981), environment and organization structure (Lenz, 1981) or strategy, structure and environment (Miller, 1986). Following these lines, subsequent works such as those by White (1986), Levinthal (1997) or Siggelkow (2001) have highlighted the importance of internal and external fit to achieve a better position than competitors. 
Among empirical contributions, studies by Grinyer et al. (1988), Hansen and Wernerfelt (1989), Collis (1991) or Rivkin (2000) have revealed that both external (market share, entry barriers or size) and internal factors (management style, control of human resources, complex strategies or working conditions, etc.) determine business success. For their part, Maijoor and Van Witteloostuijn (1996), Miller and Shamsie (1996) or Fahy (1996) have tested the positive relationships between industry and firms' resources.

Within this framework, the objective of the present study is to contribute empirical evidence that may be instrumental to a greater understanding of the factors behind the firm's competitive position, based on the joint consideration of both strategic trends. In order to achieve this, we have used a survey carried out in 1999 on 287 executives from the service sector in the province of Santa Cruz de Tenerife, where we analysed the differential factors that distinguish the strategic performance of competitive and non-competitive firms, by jointly assessing the variables representative of the sector in which the firm performs (five competitive forces defined by Porter) and variables of an internal feature (managerial decisions).

The use of the cluster analysis to classify firms according to their level of competitiveness based on managers' perception, and the application of the $S e e 5$ induction algorithm to determine differential factors that distinguish competitive from non-competitive firms, place our main contribution in the methodological field.

Our work has been structured as follows: the second section presents the methodology developed to achieve the previous objectives, the third describes the results obtained by applying the inductive analysis, and finally, we summarize the main conclusions.

\section{METHODOLOGY}

\section{Characteristics of the Sample}

The data were extracted from a survey carried out in 1999, whose main characteristics are set down in the card below:

- Population: 2368 small and medium size firms in the service sector located in the province of Santa Cruz de Tenerife, Canary Islands, Spain.
- Direct Interview: with the manager or top managerial position ${ }^{5}$ undertaken by a field crew comprising of nine persons trained for this purpose.

- Date of survey: 5th and 30th April 1999.

- Selection process: 600 firms were chosen from the Economic Activity Tax list, according to a double stratification process, proportional to the weight of the strata (per activity sector and production branch) with a final simple random selection.

- Completed Questionnaires: 287 of the 600 firms initially chosen. This was due to the impossibility of physically locating 313 firms, owing to a lack of information concerning their business address or to business closure.

- Sampling error: lower than $\pm 5.5 \%$, which guarantees $95.5 \%$ reliability.

From this initial sample of 287 firms, 38 questionnaires were eliminated because they belonged to low representational activities or because they lacked accurate information about their activity sector, and 76 questionnaires were eliminated due to absences in observations concerning some of the variables to be analysed. As a result, we obtained a final study sample of 173 firms, whose main characteristics are given in Chart 1 :

- All the analysed firms belong to the service sector, where commercial activity predominates for $64 \%$ of the firms in the sample (Chart 1). The service sector was chosen for study because of its importance within the economic activity of Canary Islands, involving $86 \%$ of firms (Chart 2).

- Age is a distinguishing feature of the firms included in the sample: around $46 \%$ have been operating for over 10 years, while just over $9 \%$ have been doing so for 50 years. This data demonstrate a long-standing tradition of activity in commerce and services in the economic structure of Canary Islands.

- Individual firms and private limited companies constitute the legal framework preferred by the entrepreneurs polled, representing over $73 \%$ of the total sample ( 40.5 and $32.9 \%$, respectively). This fact, along with a scant presence of public limited companies (16.2\% of all firms), gives us an idea of the small size of Canary Islands' firms.

- The work force of almost $40 \%$ of the firms included in the sample is made up of 2 workers 
or fewer. On the contrary, firms that declare the presence of over 10 employees are fewer than $15 \%$. These data, along with data shown in Chart 2, confirm the previous perception about the reduced size of firms.

\begin{tabular}{|c|c|c|}
\hline Main activity & $\mathrm{N}^{\circ}$ Firms & $\%$ \\
\hline Commerce & 111 & 64.2 \\
\hline Hotel trade & 18 & 10.4 \\
\hline $\begin{array}{l}\text { Transport, Warehousing and Com- } \\
\text { munications }\end{array}$ & 8 & 4.6 \\
\hline Financial Intermediation & 12 & 6.9 \\
\hline $\begin{array}{l}\text { Real Estate Activities and Entre- } \\
\text { preneurial Services }\end{array}$ & 14 & 8.1 \\
\hline $\begin{array}{l}\text { Other social activities and person- } \\
\text { nel services }\end{array}$ & 10 & 5.8 \\
\hline Total & 173 & 100 \\
\hline Distribution by age & $\mathrm{N}^{\circ}$ Firms & $\%$ \\
\hline Up to 5 years & 48 & 31.5 \\
\hline Between 6 and 10 years & 34 & 22.4 \\
\hline Between 11 and 25 years & 30 & 19.7 \\
\hline Between 26 and 50 years & 26 & 17.1 \\
\hline Over 50 years & 14 & 9.3 \\
\hline Average age of firms in the sample & 19,1 & 一 \\
\hline Distribution by legal personality & $\mathrm{N}^{\circ}$ Firms & $\%$ \\
\hline Individual firm & 70 & 40.5 \\
\hline Public Liability company & 28 & 16.2 \\
\hline Private limited company & 57 & 32.9 \\
\hline Cooperative & 1 & 0.6 \\
\hline Workers' Cooperative & 3 & 1.7 \\
\hline Others & 14 & 8 \\
\hline Distribution by number of workers & $\mathrm{N}^{\circ}$ Firms & $\%$ \\
\hline No salaried staff & 22 & 12.7 \\
\hline From 1 to 2 salaried staff & 46 & 26.6 \\
\hline From 3 to 9 salaried staff & 80 & 46.2 \\
\hline From 10 to 19 salaried staff & 9 & 5.2 \\
\hline From 20 to 49 salaried staff & 12 & 6.9 \\
\hline From 50 or more & 4 & 2.3 \\
\hline
\end{tabular}

Source: Own elaboration.
The insular character of Canary Islands, their remoteness from main markets and a lack of industrializable natural resources have left their mark on the economic structure of the islands, giving rise to a high level of tertiarization based on tourism and commercial activities. ${ }^{6}$

Apart from large number of firms present in a limited market of long-standing tradition, firms in the service sector, particularly commercial ones, find up against a series of structural difficulties that call for a closer analysis of the factors that distinguish their competitiveness. These difficulties include:

- An insular nature and remoteness from the main continental markets have a marked effect on firms' commercial relations, restricting the size of the market in which they move, in most cases merely insular and not even regional. These circumstances preclude the appearance of economies of scale.

- Remoteness from external markets obliges firms to sustain higher costs due to transport overcharge, and, subsequently, to create greater stocks of raw materials and manufactured products.

- Being an international tourist destination gives rise to greater commercial density in tourist areas and a unique profile of commercial activities associated with this sector (high fragmentation, smaller size businesses, specific products).

- The predominance of small size firms was altered by the appearance of superstores in the early 1990s, with subsequent changes in consumer purchasing habits. The result of this new situation is that traditional businesses are permanently seeking a formula to increase their competitiveness.

\section{Chart 2. Canary Firms. Distribution by activity and number of workers.}

\begin{tabular}{|c|c|c|c|c|c|c|c|c|}
\hline \multirow[t]{2}{*}{ Total } & \multicolumn{2}{|l|}{ Total } & \multicolumn{2}{|c|}{ Industry } & \multicolumn{2}{|c|}{ Construction } & \multicolumn{2}{|c|}{ Services } \\
\hline & 100,008 & $100 \%$ & 5,891 & $6 \%$ & 8,378 & $8 \%$ & 85,739 & $86 \%$ \\
\hline No salaried staff & 51,044 & $51 \%$ & 2,239 & $38 \%$ & 3,387 & $40 \%$ & 45,418 & $53 \%$ \\
\hline From 1 to 2 salaried staffs & 27,085 & $27 \%$ & 1,651 & $28 \%$ & 1,893 & $23 \%$ & 23,541 & $27 \%$ \\
\hline From 3 to 9 salaried staffs & 15,411 & $15 \%$ & 1,302 & $22 \%$ & 1,848 & $22 \%$ & 12,261 & $14 \%$ \\
\hline From 10 to 19 salaried staffs & 3,532 & $4 \%$ & 369 & $6 \%$ & 630 & $8 \%$ & 2,533 & $3 \%$ \\
\hline From 20 to 49 salaried staffs & 2,002 & $2 \%$ & 235 & $4 \%$ & 416 & $5 \%$ & 1,351 & $2 \%$ \\
\hline From 50 or over & 934 & $1 \%$ & 95 & $2 \%$ & 204 & $2 \%$ & 635 & $1 \%$ \\
\hline Total salaried staff & 100,008 & $100 \%$ & 5,891 & $100 \%$ & 8,378 & $100 \%$ & 85,739 & $100 \%$ \\
\hline
\end{tabular}

Source: INE (2003) 
Firm Classification: Competitive-Non-competitive

The achievement of this research's objective requires a classification design to differentiate between competitive and non-competitive firms, and a way in which to assess firms' competitiveness.

Business competitiveness has traditionally been understood from the perspective of market success (Michalet, 1981; Mathis et al., 1988). In this sense, a firm is considered competitive when it is capable of maintaining or increasing its sales volume compared with the total sales of the market where it operates.

Despite the fact that market share has been explained by economies of scale, market power, and product quality valuation as a determining factor for business returns (Jacobson, 1988), there is no conclusive empirical evidence of this relationship on the basis of these variables. ${ }^{7}$

Alternatively, developments in the field of Industrial Economics and the firm have explained that, aside from the possible cause-effect relation between market share and returns, both elements may be simultaneously affected by specific factors, such as industry structure, the adopted competitive strategy or internal resources, particularly intangibles.

Nevertheless, despite the decisive role of intangible assets (Itami, 1987; Teece et al., 1994; Markides and Williamson, 1996; Teece, 1998), they have been permanently absent from the models that attempt to assess business competitiveness. $^{8}$

This circumstance is essentially justified by the following arguments:

- Normal accountancy systems do not incorporate intangible assets as an integral part of equity, owing to difficulties of identification and valuation (Grant, 1991; Wallman, 1995; Wallman, 1996).
- Only some intangible assets can be protected with property rights through patents, reproduction rights, brand registration, etc. (Hall, 1992).

Despite these difficulties, we understand that a complete framework aiming to measure and assess business competitiveness cannot be restricted to quantitative indicators, but it must explicitly include measurements of the firm's qualitative results through their possession of intangibles and competencies. ${ }^{9}$

Chart 3 shows the variables used in our research to assess the level of business competitiveness. The guidelines for the selection process were as follows:

1. We adopted a multi-dimensional scale by combining quantitative indicators of positioning in the product market (market share, profits and performance), with measurements of the qualitative results achieved by firms thanks to the possession of intangible assets. We used a subjective assessment method by which firms' managers made a self-assessment of their organization compared with industry competitors. $^{10}$

2. Based on a revision of the literature, we have chosen the intangibles usually considered as key factors to business success (Hansen and Wernerfelt, 1989; Hall, 1992; Hall, 1993; Amir and Lev, 1996; Brooking, 1997; Grant, 1997; Lev and Zarowin, 1998; Aboody and Lev, 1998; Young, 1998; Vickery, 1999, etc.). This choice was combined with the operative aims of the questionnaire, which limited the number of indicators considered.

For this measurement, we used a method of subjective assessment by which the entrepreneur should position himself according to the degree of advantage perceived in relation to competitors and to the 14 indicators selected (Chart 3). For this, we used a Likert scale from 1 to $3(1=$ very advantageous situation; $3=$ very disadvantageous situation). ${ }^{11}$

\section{Chart 3. Variables used to determine firms' level of competitiveness.}

\begin{tabular}{llrl}
1 & Market share & 8 & Managers' educational background \\
2 & Profits & 9 & Customer royalty \\
3 & Returns & 10 & Supplier loyalty \\
4 & Technological provision & 11 & Location of establishment \\
5 & Financial management & 12 & Employees' professional know-how \\
6 & Quality of products-services & 13 & Employees' commitment and loyalty \\
7 & After sales service & 14 & Firm's reputation \\
\hline
\end{tabular}


We applied a cluster analysis to the 173 firms in the sample to avoid subjectivity when categorizing firms as competitive or non-competitive and to be able to work simultaneously with the 14 indicators selected.

Cluster is a multi-variant analysis whose main purpose is to categorize individuals into groups, so that the characteristics of individuals belonging to the same group are as homogeneous as possible between them and highly heterogeneous in relation to those of other groups. The classifying method applied in this case was the $k$-means cluster analysis. $^{12}$

By applying the cluster analysis, three conglomerates of firms have been obtained (non-competitive, average level of competitiveness and competitive). The valuation of the $F$ statistic from the variance analysis led us to observe a limited level of significance in the indicator 'location of establishment', ${ }^{13}$ in relation to the remaining variables. This circumstance led us to perform a second cluster analysis by only taking into account the thirteen remaining variables. Chart 4 illustrates the final distribution of the groups.

\section{Chart 4. Distribution of the sample by conglom- erates.}

\begin{tabular}{ll} 
Conglomerate & Number \\
\hline Conglomerate 1. Non-competitive Firms & 38 \\
Conglomerate 2. Average level competitive Firms & 80 \\
Conglomerate 3. Competitive Firms & 55
\end{tabular}

Source: Own elaboration.

Chart 5. Variance analysis.

\begin{tabular}{lll} 
Variable & $\boldsymbol{F}$-Statistic & Significance \\
\hline Market share & 39.480 & 0.000 \\
Profits & 42.014 & 0.000 \\
Returns & 50.893 & 0.000 \\
Technological provision & 84.294 & 0.000 \\
Financial management & 48.970 & 0.000 \\
Quality of products-services & 27.156 & 0.000 \\
After sales service & 25.845 & 0.000 \\
Managers' educational background & 61.608 & 0.000 \\
Customer loyalty & 31.649 & 0.000 \\
Suppliers' loyalty & 19.569 & 0.000 \\
Employees' professional know-how & 56.875 & 0.000 \\
Employees' commitment and loyalty & 35.524 & 0.000 \\
Firm's reputation & 30.829 & 0.000 \\
\hline
\end{tabular}

Source: Own elaboration.
For the latter, the values attained by the $F$ statistics of the 13 variables considered (Chart 5) reveal the positive contribution that each made towards group distinction. The variables that contributed most information to defining firms according to their level of competitiveness were: technological provision, managers' educational background, employee know-how, performance and financial management.

\section{Variable Selection}

Once the groups of firms have been constituted, we select the variables that allow us to assess the differential aspects that distinguish the strategic behaviour of competitive vis-à-vis non-competitive firms. To this end, we have sounded out managers' opinions by considering two types of variables:

1. Perception about the attraction of their activity sector: based on the five competitive forces defined by Porter (degree of rivalry between existing competitors, likelihood of new competitor entry, threat of substitute products or services, supplier and customer negotiating power). For each of them, the manager was to position himself on a Likert scale of 1-3 $(1=$ very high, $2=$ high, $3=$ normal $)($ Chart 6$)$.

2. Managers' strategic decisions with regard to: the way to compete in the product market, specialization, investment, technological innovation, internationalization and business growth (expansion and diversification). The manager was to position himself between the different alternatives given according to their degree of correspondence with the activities undertaken by his firm.

\section{Analytical Technique}

To achieve the ultimate goal of our research (evaluation of the differential aspects that distinguish competitive from non-competitive firms), based on the joint assessment of the variables considered, we have used Quinlan's See5 package (1997).

This package descends from the Concept Learning System introduced by Hunt et al. (1966). This algorithm performs successive binary participations of the explanatory variables, through inductive learning ${ }^{14}$ to construct a classification tree. This tree is constructed so that, 


\section{Chart 6}

Variables represented in the study

Scale of the variables

(a) Industry variables.

Perception about number of competitors Perception of rivalry between competitors

Perception about the likelihood of new competitor entry

Perception about the threat of substitute product or service entry

Perception about supplier negotiating power

Perception about customer negotiating power

(b) Managerial decision variables

Way of competing in the product market

Customer specialization

Specialization in range of products

Specialization by geographical areas.

Investment decisions

Incorporation of informatics tools

Area of activity

Relevance of imports over purchases

Relevance of exports over sales

Business Expansion

Expansion: development in traditional markets and products

Expansion: new products, traditional markets Expansion: new markets, traditional products Diversification: new markets, new products
1 - Very high, 2 - High, 3 - Normal

1 - Very high, 2 - High, 3 - Normal

1 - Very high, 2 - High, 3 - Normal

1 - Very high, 2 - High, 3 - Normal

1 - Very high, 2 - High, 3 - Normal

1 - Very high, 2 - High, 3 - Normal

Source: Own elaboration.

according to an enthropic measurement or quantity of information, the variable contributing the most information is chosen in each partition.

Using the tree, easily interpretable classification rules are elaborated facilitating a definition of the characteristics that most differentiate between the two initially established groups: competitive and non-competitive firms. The rules are constructed according to the principle of Minimum Description Length (MD), which guarantees a percentage of classification successes almost as high as those obtained with the tree.

The advantages of this algorithm include a greater explanatory capacity, with simpler, easily understood models that are more user-friendly than those obtained by other inductive methods (artificial neuronal networks), or by methods of multi-variant analysis (discriminant or logit). Furthermore, through its learning process, this algorithm is known for its greater capacity to filter the noise that accompanies subjective information (surveys), while offering better results when the number of individuals (cases) is not very high (as occurs in our research).

In addition to the reasons mentioned above, this choice of technique is justified by its greater flexibility, since no previous hypothesis about data structure and interactions is required, and it is not subject to the normality restrictions of variable distribution, or to their dichotomic characteristics. Chart 7 shows the Kolmogorov-Smirnov normality contrast and how the variables considered in our study as potentially explanatory are far removed from reality.

For an easier identification of variables differentiating between competitive and non-competitive firms, we have excluded average competitive level firms from the See5, which has reduced the analysis sample to 93 cases: 38 non-competitive and 55 competitive. Sixteen of these 93 have been 


\section{Chart 7. Normality test for explanatory variables. Kolmogorov-Smirnov test.}

\begin{tabular}{lll} 
Explanatory variables & Kolmogorov-Smirnov Z & Asintotic significance (bilateral) \\
\hline Perception about number of competitors & 4.441 & 0.000 \\
Perception of rivalry between competitors & 3.268 & 0.000 \\
Perception about the likelihood of new competitor entry & 3.994 & 0.000 \\
Perception about the threat of substitute product & 4.669 & 0.000 \\
Perception about supplier negotiating power & 4.962 & 0.000 \\
Perception about customer negotiating power & 4.313 & 0.000 \\
Ways of competing in the product market & 5.370 & 0.000 \\
Specialization in customers & 4.789 & 0.000 \\
Specialization in product range & 5.098 & 0.000 \\
Specialization by geographical areas & 5.044 & 0.000 \\
Investment decision & 4.579 & 0.000 \\
Incorporation of informatics tools & 5.526 & 0.000 \\
Area of activity & 5.530 & 0.000 \\
Relevance of imports over purchases & 3.086 & 0.000 \\
Relevance of exports over sales & 5.217 & 0.000 \\
Expansion: development in traditional markets and products & 2.948 & 0.000 \\
Expansion: new products, traditional markets & 4.892 & 0.000 \\
Expansion: new markets, traditional products & 4.107 & 0.000 \\
Diversification: new markets, new products & 2.948 & 0.000 \\
\hline
\end{tabular}

Source: Own elaboration.

\section{Chart 8. Decision tree for differentiating between competitive and non-competitive firms.}

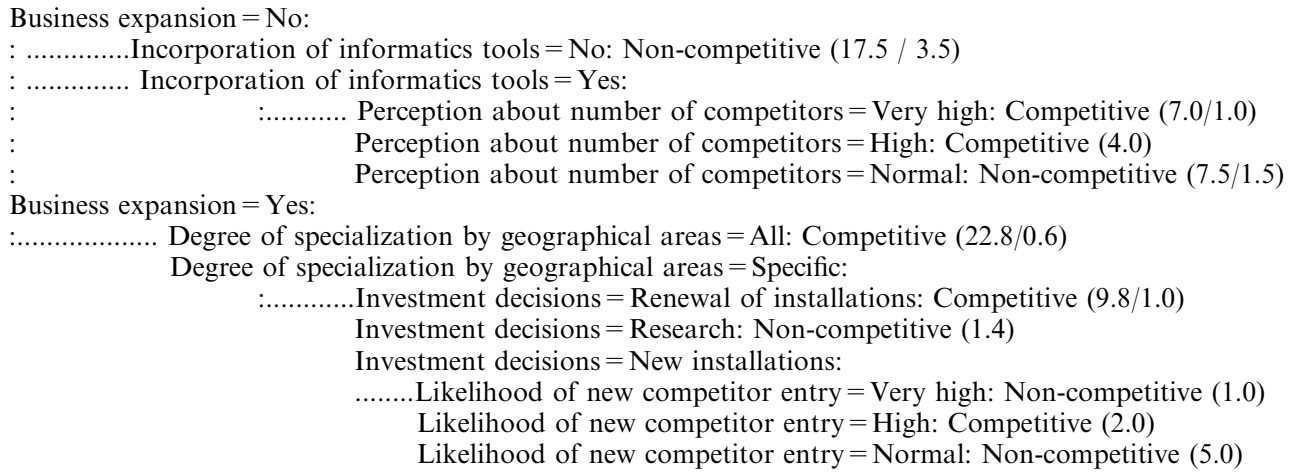

Source: Own elaboration.

reserved for the validation process, leaving the training sample with 48 competitive and 29 noncompetitive firms, which will be used to generate the decision tree and rules.

\section{RESULTS}

The results obtained from applying the See5 algorithm, by interpreting the decision tree (Chart 8) and the set of generated rules (Chart 9), have enabled us to discover the variables that mark the biggest strategic differences between competitive and non-competitive firms. The comparative analysis of these firms will be complemented with a descriptive reading of the survey results (Appen$\operatorname{dix}$ A). ${ }^{15}$

The Business Expansion variable is presented as contributing most information, dividing the tree into two main branches. Thus, approximately $69 \%$ of correctly classified competitive firms show a positive attitude towards growth (branch 2), as opposed to an identical percentage of noncompetitive firms that have not expanded their business (branch 1).

In this manner, as shown in Appendix A, expansion in the same activity sector ${ }^{16}$ is revealed as the strategic growth option most frequently implemented by all the firms analysed and is 


\section{Chart 9. Decision rules for differentiating between competitive and non-competitive firms.}

Rule 1: (coverage 20)

Degree of specialization by geographical areas $=$ All

Business expansion $=$ Yes

- > Competitive class (0.955)

Rule 2: (coverage 22)

Investment decisions $=$ Renewal of installations

Business expansion $=$ Yes

-> Competitive class $(0.917)$

Rule 3: (coverage 6)

Likelihood of new competitor entry $=$ High

Investment decisions $=$ New installations

- > Competitive class $(0.875)$

Rule 4: (coverage 4)

Perception of number of competitors $=$ High

Incorporation of informatics tools $=$ Yes

Business expansion $=$ No

- > Competitive class $(0.833)$

Rule 5: (coverage 26)

Perception of number of competitors $=$ Very high

Incorporation of informatics tools $=$ Yes

- > Competitive class $(0.821)$
Rule 6: (coverage 6)

Likelihood of new competitor entry $=$ Normal

Degree of specialization by geographical areas $=$ Specific

Investment decisions $=$ New installations

- > Non-competitive class $(0.875)$

Rule 7: (coverage 17)

Incorporation of informatics tools $=\mathrm{No}$

Business expansion $=$ No

- > Non-competitive class $(0.789)$

Rule 8: (coverage 7)

Perception of number of competitors $=$ Normal

Incorporation of informatics tools $=\mathrm{No}$

Business expansion $=$ No

- > Non-competitive class $(0.778)$

Rule 9: (coverage 5)

Investment decisions $=$ research

- > Non-competitive class $(0.714)$

Source: Own elaboration.

specially relevant for competitive firms. The latter, in comparison with non-competitive firms, are also distinguished by a greater propensity towards incorporating new goods and/or services as opposed to marketing similar products and a decided inclination towards seeking new markets rather than expanding into similar ones.

RBV argues that the expansion of firms' activities towards new products and/or markets is based on an excess of resources and capabilities susceptible to multiple uses, from which the firm will maintain or develop sustainable competitive advantages. Firms with an excess of specific physical and intangible resources will more likely grow in the direction of business which is proximal or similar to their original activity (Montgomery and Wernerfelt, 1989; Chatterjee and Wernerfelt, 1991). This is the behaviour demonstrated by the majority of the competitive firms polled.

Descending the first branch of the tree, we discover managers' strategic attitude towards technological innovation as a second level discriminatory factor, which is represented by the variable Incorporation of New Informatics Tools. The $46 \%$ of correctly classified non-competitive firms have neither included an informatics tool nor expanded their business (Rule 7), whereas competitive firms show a greater awareness of this strategic requirement (Appendix A).

The apparent simplification of identifying technological innovation with the incorporation of new informatics tools is justified by the decisive role that they play as a basis for incorporating the wide range of possibilities offered by the new information and communication technologies, thereby facilitating the decision-making process and providing new marketing channels.

Bearing in mind the profile of the firms analysed (essentially commercial services) for the latter case, the role of Internet, as indicated by Porter (2001), is especially significant, since it has created new opportunities for both supply and demand to articulate and develop sustainable competitive advantages based on cost and differentiation.

Executives in competitive firms demonstrate greater skilfulness at conceiving, developing and exploiting information technologies. These results are in accordance with those obtained by Powell and Dent-Micallef (1997) and Mata et al. (1995), which determine the likelihood of achieving competitive advantages from information 
technology based on the existence of other intangible resources. ${ }^{17}$

The Perception of the Number of Competitors in the Industry variable is seen as having the smallest classificatory capacity of those that make up the first branch of the tree. This capacity is significant for competitive firms, since $52 \%$ perceive the number of competitors as high or very high (rules 4 and 5).

Taking into account the fact that $86 \%$ of Canary firms belong to the service sector (INE, 2003) and that this coincides with the entire sample analysed, we can infer that competitive firms have a more accurate perception of environment complexity. ${ }^{18}$ This result establishes a link with previous research emphasizing managers' skilfulness at accurately perceiving the environment as being a determining factor of business returns, since it conditions the definition of successful strategies (Day and Nedungadi, 1994; Liao and Greenfield, 1997).

From the RBV, obstacles in the way of a correct perception and adaptation of the industry would be explained by a firm's lack of resources and capabilities, such as deficient entrepreneurial capacity or insufficient organizational means (for example, information systems).

An analysis of the second branch of the tree reveals the Degree of Firm Specialization by Geographical Area as a second level differentiating factor, by correctly classifying $46 \%$ of competitive firms under the commercial strategy of cornering the entire market (branch 2). In the same sense, decision rule 1 demonstrates that approximately $40 \%$ of these firms perform in a much wider geographical area, besides showing a positive attitude towards business expansion.

These issues explain why the majority of competitive firms market their goods and/or services in regional, national or international markets, while non-competitive firms focus their performance on a local market (Appendix A).

In this second branch, Investment Decisions are presented as a third level explanatory factor when establishing differences between competitive and non-competitive firms. Thus, $42 \%$ of the correctly classified competitive firms have made some effort to renew and modernize their productive structure (Rule 2).

In this fashion, despite the fact that the efforts made to incorporate new installations reveal no performance differences between competitive and non-competitive firms in this sphere, renovating existing facilities, the investment strategy most frequently used by executives from both kinds of firms, is especially significant for competitive ones (Appendix A).

The perception variable Likelihood of New Competitor Entry is situated as a final differentiating factor (fourth level). Analysis suggests that $11 \%$ of competitive firms consider this likelihood as high (rule 3), as opposed to the less dynamic view of non-competitive firms, $19 \%$ of whom qualify this as a normal risk (rule 6). These results strengthen the argument about the greater complexity and accuracy with which competitive firms perceive competitive conditions in their activity sector.

Chart 10 shows the high classificatory capacity obtained from the rules and decision tree. For the first case, the success index figures as $89 \%$, while the percentage of well classified firms, according to the nine rules generated, is placed at $92.2 \%$.

Given that these values refer to 'training data', we have applied two types of analysis incorporating the See5 algorithm to validate the accuracy and capacity of the results obtained: firstly, a crossvalidate analysis; and secondly, a validation analysis of the classificatory capacity of this model with the 16 firms previously reserved for that purpose.

The crossvalidate analysis enables us to recalculate the decision tree based on different initial samples. The new samples are obtained by eliminating one case each time the process is repeated. The random composition of the samples has led us to repeat this procedure 50 times, with a mean error of around $12 \%$ and a typical deviation of $1.4 \%$. The new decision rules and trees obtained in this process confirm the importance of the previous variables for distinguishing the strategic performance of competitive vis-à-vis non-competitive firms.

\section{Chart 10. Classificatory capacity of rules and decision tree.}

Training data assessment (77 cases):

Decision tree

\begin{tabular}{|c|c|c|c|}
\hline Size & Errors & $\mathrm{N}^{\circ}$ & Errors \\
\hline 10 & $8(10.4 \%)$ & 9 & $6(7.8 \%)$ \\
\hline (a) & \multicolumn{3}{|l|}{ (b) $<-$ classified as } \\
\hline 44 & \multirow{2}{*}{\multicolumn{3}{|c|}{$\begin{array}{l}4 \quad \text { (a): Competitive class } \\
27 \text { (b): Non-competitive class }\end{array}$}} \\
\hline 2 & & & \\
\hline
\end{tabular}

Source: Own elaboration. 


\begin{tabular}{|c|c|c|c|}
\hline \multicolumn{4}{|c|}{ Chart 11.} \\
\hline \multicolumn{4}{|c|}{ Validation data assessment (16 cases): } \\
\hline \multicolumn{2}{|c|}{ Decision tree } & \multicolumn{2}{|c|}{ Rules } \\
\hline Size & Errors & $\mathrm{N}^{\circ}$ & Errors \\
\hline 10 & $0(0.0 \%)$ & 9 & $0(0.0 \%)$ \\
\hline (a) & (b) $<-$ & -- & \\
\hline 7 & (a): $\mathrm{Cc}$ & & \\
\hline & 9 (b): $\mathrm{N}$ & class & \\
\hline
\end{tabular}

Source: Own elaboration.

This is also confirmed by the decision trees obtained for the 16 firms in the validation sample, whose classificatory capacity reached $100 \%$ (Chart 11).

\section{CONCLUSIONS}

The results from the analysis defined in the previous pages have enabled us to comprehend the strategic variables that largely explain the competitive position of a sample of firms.

For this purpose, we have jointly assessed variables representative of the characteristics of the industry where the firm performs (economic paradigm), based on the five competitive forces defined by Porter, with variables characteristic of the organizational paradigm, which locate the firm's internal factors in the epicentre of competitive success. For the latter, we have concentrated on managerial capabilities because of the significant role played by executives in the strategic decision-making process.

The results from the See 5 induction algorithm indicate that both groups of variables intermingle when explaining the competitive position achieved by firms. However, in the first branches of the tree, the strategic variables providing most information for differentiating between competitive and noncompetitive firms belong to the internal category (Decisions about Business Expansion, Incorporation of new Informatics Tools and Degree of Specialization of the Firm by Geographical Area), while external variables (Perception about the Number of Competitors in the Activity Sector and Likelihood of New Competitor Entry) are less significant.

The important classificatory capacity, demonstrated by these variables in the See5 induction analysis, and the low percentage of error when cataloguing new firms not included in the initial sample, highlight the importance of these factors for explaining the competitive capacity of the firms analysed.

In this sense, we would like to point out that the methodological process is the most relevant contribution of this work, and more specifically in the following aspects:

- The data have been extracted from a survey aimed at the top executives of the firms analysed: the main figures in the decisionmaking process. This has enabled us to include, in the classification process, measurements of the qualitative results with intangible resources.

- Cluster analysis has been used to objectively classify firms as competitive and non-competitive, depending on an ample group of indicators (14 variables). It has permitted us to overcome the arbitrary nature that usually characterizes competitive positioning studies, since it is normally the researcher who classifies firms using a small number of variables.

Moreover, applying the See5 induction algorithm of rules and decision trees has enabled us to identify the factors that contribute most information for differentiating between competitive and non-competitive firms. This artificial intelligence technique provides qualitative information with a better fit, as opposed to the multivariant statistical techniques most frequently used in this kind of study.

- The characteristics of the sample analysedsmall and medium size firms in the service sector-compared with the usual tendency of this kind of research, aimed at large firms (especially in the industrial sector).

A straightforward reading of the results obtained leads to the conclusion that a joint consideration of both internal and external factors is important when analysing the causality chain of entrepreneurial competitiveness. Therefore, it would be advisable to continue along these lines of integrative research, which seeks to create one single model from the incorporation of the two trends that endeavour to explain competitiveness: internal resources and capabilities and explanatory industry factors.

\section{Acknowledgements}

The writers are grateful to Mark H. Hansen for his precise comments concerning the draft of this article. 
APPENDIX A: ANALYSIS OF THE FREQUENCY OF THE VARIABLES IN THE SURVEY

\begin{tabular}{|c|c|c|c|}
\hline Variables & Competitive & Non-Competitive & Differences \\
\hline \multicolumn{4}{|c|}{ Significant variables according to $S e e 5$} \\
\hline Business expansion & $\begin{array}{l}\text { Yes: } 71 \% \\
\text { No: } 29 \%\end{array}$ & $\begin{array}{l}\text { Yes: } 34 \% \\
\text { No: } 66 \%\end{array}$ & $\begin{array}{l}\text { - Significant differences re- } \\
\text { garding decision to expand. }\end{array}$ \\
\hline $\begin{array}{l}\text { Incorporation of } \\
\text { informatics tools }\end{array}$ & $\begin{array}{l}\text { Yes: } 82 \% \\
\text { No: } 16 \%\end{array}$ & $\begin{array}{l}\text { Yes: } 53 \% \\
\text { No: } 47 \%\end{array}$ & $\begin{array}{l}\text { - Competitive firms tend to } \\
\text { incorporate informatics } \\
\text { tools. }\end{array}$ \\
\hline $\begin{array}{l}\text { Perception about number of } \\
\text { competitors }\end{array}$ & $\begin{array}{l}\text { High-Very high: } \\
78.18 \% \\
\text { Normal: } 21.82 \%\end{array}$ & $\begin{array}{l}\text { High-Very high: } \\
52.63 \% \\
\text { Normal: } 47.37 \%\end{array}$ & $\begin{array}{l}\text { - Competitive firms, unlike } \\
\text { non-competitive firms, per- } \\
\text { ceive their environment as } \\
\text { having a larger number of } \\
\text { competitors. }\end{array}$ \\
\hline $\begin{array}{l}\text { Degree of specialization by } \\
\text { geographical areas }\end{array}$ & $\begin{array}{l}\text { All: } 53 \% \\
\text { Specific: } 38 \%\end{array}$ & $\begin{array}{l}\text { All: } 16 \% \\
\text { Specific: } 71 \%\end{array}$ & $\begin{array}{l}\text { - Competitive firms have a } \\
\text { wider sphere of action } \\
\text { than their non-competitive } \\
\text { counterparts. }\end{array}$ \\
\hline Investment decisions & $\begin{array}{l}\text { Renewal of in- } \\
\text { stallations: } 69 \% \\
\text { Research: } 11 \% \\
\text { New installa- } \\
\text { tions: } 20 \%\end{array}$ & $\begin{array}{l}\text { Renewal of instal- } \\
\text { lations: } 53 \% \\
\text { Research: } 8 \% \\
\text { New installations: } \\
39 \%\end{array}$ & $\begin{array}{l}\text { - The strategic option pre- } \\
\text { ferred by competitive firms } \\
\text { is to renew and modernize } \\
\text { existing installations }\end{array}$ \\
\hline $\begin{array}{l}\text { Perception of the likelihood } \\
\text { of new competitor entry }\end{array}$ & $\begin{array}{l}\text { High-Very high: } \\
58.18 \% \\
\text { Normal: } 41.82 \%\end{array}$ & $\begin{array}{l}\text { High-Very high: } \\
36.84 \% \\
\text { Normal: } 60.53 \%\end{array}$ & $\begin{array}{l}\text { - Competitive firms perceive } \\
\text { a greater likelihood of new } \\
\text { competitor entry. }\end{array}$ \\
\hline
\end{tabular}

Insignificant variables according to See5

Perception of rivalry between competitors

Perception of threat of substitute products or services

Perception of suppliers' negotiating power

Perception of customer negotiating power

Decisions about ways of competing in the market

Customer specialization

Product specialization
High-Very high: $78 \%$ Normal: $22 \%$

High-Very high: $44 \%$ Normal: 55\%

High-Very high: $40.20 \%$

Normal: $59.80 \%$

High-Very high: $52.23 \%$

Normal: $46.77 \%$

Prices: $16.7 \%$

Quality: $77.8 \%$

Joint: $5.6 \%$

Unspecialised: $65 \%$

Specialised: $29 \%$ Unspecialised: $47 \%$

Specialised: $45 \%$
High-Very high: $74 \%$

Normal: $26 \%$

High-Very high: $38.2 \%$

Normal: $58.6 \%$

High-Very high: $45.25 \%$

Normal: $54.75 \%$

High-Very high: $48.2 \%$

Normal: $50.8 \%$

Prices: $27 \%$

Quality: $73 \%$

Joint: (-)

Unspecialised: $53 \%$

Specialised: $37 \%$

Unspecialised: $49 \%$

Specialised: $50 \%$
- There is hardly any difference in the perception of the degree of rivalry between competitors.

- No great differences are appreciated in the degree of perception about the threat of substitute products or services.

- There is no great difference between both groups of firms regarding supplier negotiating power.

- There is hardly any difference in customer negotiating power.

- Unlike non-competitive firms, competitive firms tend to give priority to quality more than price.

- Competitive firms target wider segments of the market.

- There are barely any differences between both groups of firms. 
Sphere of action

Relevance of imports over
purchases

Relevance of exports over sales

Product expansion

Market expansion
International: International: (-) $10.9 \%$

National: $9.1 \% \quad$ National: $2.6 \%$

Other islands: Other islands:

$43.6 \% \quad 23.7 \%$

Local: $36.4 \%$

High-Very high:

$38.9 \%$

Normal-Low:

$59.6 \%$

High-Very high:

$5.70 \%$

Normal-Low:

$94.3 \%$

Similar: $25.6 \%$

New: $71.8 \%$

Similar: $29.6 \%$

New: $70.8 \%$

Local: $73.7 \%$

High-Very high:

$40 \%$

Normal-Low:

$58.8 \%$

High-Very high:

$2.9 \%$

Normal-Low:

$97.1 \%$

Similar: $39.5 \%$

New: $61.5 \%$
Similar: $55.6 \%$

New: $44.4 \%$
- Non-competitive firms tend to limit their actions to the local market, unlike competitive firms who adopt a more global attitude.

- There are few differences in importing behaviour.

- Although there is a minor difference, competitive firms show a greater tendency to export.

- Both groups prefer to develop new products, though this tendency is greater with competitive firms.

- There are differences in the strategic preferences of each group.

Source: Own elaboration.

\section{Notes}

1. Along these lines, works such as those by Caves and Porter (1977), Porter (1980, 1985), Miller (1986), Miller and Friesen (1986) and Buzzell and Gale (1987) analyse the environmental conditions in which a firm would obtain a higher level of returns.

2. In spite of the initial contribution of Penrose (1959), the official birth of this approach is usually given as 1984 with the initial contributions by Wernerfelt (1984), though it is understood that development did not take place until several years later with the appearance of new theoretical and empirical studies by authors such as Barney (1986), Dierickx and Cool (1989), Aaker (1989), Prahalad and Hamel (1990), Barney (1991), Grant (1991), Hall (1992), Peteraf (1993), or Amit and Schoemaker (1993). Priem and Butler (2001) illustrate RBV's high degree of penetration, having detected since 1991 works with this approach in thirteen of the eighteen essential research subjects in the strategic area defined by Schendel and Hofer (1979).

3. It is true that managers are as much responsible for their organization's success as they are for its failure (Penrose, 1959; Reed and DeFillipi, 1990; Castanias and Helfat, 1991; Lado and Wilson, 1994).

4. Harris and Helfat (1997) use Becker's classification (1964) suggesting that, at a basic level, managerial function consists of three types of capabilities: (a) generic capabilities that are transferable throughout sectors and firms, (b) sector-specific capabilities and (c) firm-specific capabilities. It is precisely the latter which forms the basis of exclusive achievements in the market (Castanias and Helfat, 1991; Harris and Helfat, 1997).

5. As shown by Chart 2, firms in Canary Islands are generally small. This circumstance explains why in many of the cases polled the manager was also the owner of the firm.

6. The Archipelago of the Canaries (Spain) comprises of seven islands and currently has a population of 1.7 million. It is located at over $1800 \mathrm{~km}$ from Madrid and almost $3000 \mathrm{~km}$ from Brussels, and, after the French DOM is the second outermost region in the European Union.According to the data from 2001, the Canaries, with 10.7 millions of foreign visitors is the leading tourist region in Spain (IET, 2003), a country that holds second place in the world tourism ranks (WTO, 2003). Tourist consumption in the Canaries represents around $40 \%$ of domestic consumption, which confirms the significant effect of tourist demand on the local market.

7. Proof of this is the fact that an image of quality often calls for a perception of exclusiveness, which is incompatible with high market shares (Porter, 1980); that the likelihood of competitor expansion may prevent firms from exercising their market power despite their large share (Fisher et al., 1983); or that an efficient minimum scale may be achieved with a relatively small market share (Schmalensee, 1987).

8. In this sense, Dierickx and Cool (1989) point out that, 'a number of scholars have expressed concern 
that much of the strategy literature focuses too narrowly on privileged product market positions as a basis for competitive advantage and abovenormal returns (Gabel, 1984; Wernerfelt, 1984; Barney, 1986). The fact that resource bundles need to be deployed to achieve or protect such privileged product market positions is often overlooked'.

9. Chakravarthy (1986), using a comparison between seven firms in the electronics sector recognised as being excellent (Peters and Waterman, 1982) with another seven non-excellent firms, confirms that the traditional economic-financial indicators of performance and sales cannot sufficiently explain the differences between the two groups of firms. Thus, he proposed using measurements that consider two aspects: (a) the quality of strategic changes regarding a firm's capacity of fit, and (b) the degree of satisfaction of the organization's interest groups and the running of the organization.

10. There is certain empirical evidence that subjective managerial assessments are generally quite consistent with objective business performance (Dess and Robinson, 1984; Venkatraman and Ramanujam, 1986; Smith et al., 1989), avoiding some of the problems involved in the latter. With this method, performance assessment does not depend on individual perceptions, but on objective indicators either published or accessible through a database. Restricted information and a tendency towards the use of single item scales are its main limitations.

11. Linguistic scales (for example, low, medium, high) are always preferable to numeric scales for subjective assessment methods, since the use of language reduces the respondent's bias when being questioned about complex and vague variables (Zadeth, 1965; Zimmer, 1983; Schwenk, 1984; Rangone, 1997).

12. This procedure is the most appropriate when attempting to identify groups of relatively homogeneous cases, based on a series of characteristics selected according to the likelihood of establishing a more accurate classification of individuals by allowing re-allocations between groups. With this method, the set of individuals is divided into conglomerates, so that at the end of the process each case belongs to the cluster whose centre is closest to it. The Euclidean distance is the measurement used to establish the proximity between each case and the centre of its respective cluster. The centre of the cluster is given by the mean number of individuals who make up each variable.

13. In cluster analysis, the $F$ statistic may only be used for a descriptive purpose, since the conglomerates have been created to maximize the differences between cases from different groups. Despite this, the relative size of the statistics provides information about the contribution of each variable to group separation.

14. Inductive learning is particular amongst learning techniques based on examples and its task is to induce rules from the historical data available. Each example must have the same consistent structure in a conclusion (decision) and a number of characteristics or attributes that define this conclusion or decision. Subsequently, a generalization process is produced in such a way that the decision tree correctly classifies the examples given. Furthermore, this tree is characterized as being optimum in the sense that it minimizes the number of attributes required for reaching the conclusiondecision.

15. Appendix A includes an analysis of the frequencies obtained for each (relevant and irrelevant) indicator incorporated into the survey used as initial information for this research.

16. By following Ansoff's (1965) approach to the growth vector, in addition to an increase in sales of current products in traditional markets, we have considered the introduction of current products into new markets or the sale of new products in traditional markets as decisions to expand. We have reserved using the term diversification for delimiting the simultaneous entry of the firm into new markets with new or similar products.

17. According to Keen (1993), the main difference between the economic and competitive benefits that firms obtain from information technology is due to managerial and not technical differences.

18. According to Jurkovich (1974), an environment is considered complex when there is a high number of elements affecting the firm, since this is significant for a good course of business. In the same way, a simple environment will have a small number of environmental elements that are significant for good organizational performance.

\section{REFERENCES}

Aaker DA. 1989. Managing assets and skills: the key to a sustainable competitive advantage. California Management Review 31: 91-106.

Aboody D, Lev B. 1998. The value relevance of intangibles: the case of Software Capitalization. Journal of Accounting Research 36: 161-191.

Amir E, Lev B. 1996. Value relevance of non-financial information: the wireless communications industry. Journal of Accounting and Economics 22: 3-30

Amit R, Schoemaker P. 1993. Strategic assets and organizational rent. Strategic Management Journal 14: $33-46$.

Ansoff I. 1965. Corporate Strategy. McGraw-Hill: New York.

Bain JS. 1959. Industrial Organization. Wiley: New York.

Barney JB. 1986. Strategic factor markets: expectation, luck, and business strategy. Management Science 32: 1231-1241.

Barney JB. 1991. Firm resources and sustained competitive advantage. Journal of Management 17: 99-120. 
Barney JB. 2001. Is the resource-based view a useful perspective for strategic management research? Yes. Academy of Management Review 26: 41-56.

Becker G. 1964. Human Capital. Columbia University Press: New York.

Brooking A. 1997. Management of intellectual capital. Long Range Planning 30: 364-365.

Bublitz B, Ettredge M. 1989. The information in discretionary outlays: advertising, research and development. The Accounting Review 64: 108-124.

Buzzell R, Gale B. 1987. The PIMS Principles: Linking Strategy to Performance. Free Press: New York.

Castanias RP, Helfat CE. 1991. Managerial resources and rents. Journal of Management 17: 155-171.

Castanias RP, Helfat CE. 2001. The managerial rents model: theory and empirical analysis. Journal of Management 27: 661-678.

Caves R, Porter M. 1977. From entry barriers to mobility barriers: conjectural decisions and contrived deterrence to new competition. Quarterly Journal of Economics 91: 241-262.

Chakravarthy BS. 1986. Measuring strategic performance. Strategic Management Journal 7: 437-458.

Chatterjee S, Wernerfelt B. 1991. The link between resources and type of diversification: theory and evidence. Strategic Management Journal 12: 33-48.

Chauvin KW, Hirschey M. 1993. Advertising, R\&D expenditures and the market value of the firm. Financial Management 4: 128-140.

Collis DJ. 1991. A resource-based analysis of global competition: the case of the bearings industry. Strategic Management Journal 12: 49-68.

Cool K, Schendel D. 1988. Performance differences among strategic group members. Strategic Management Journal 9: 207-224.

Day GS, Nedungadi P. 1994. Managerial representations of competitive advantage. Journal of Marketing 58: 31-44.

Dess GS, Robinson RB. 1984. Measuring organizational performance in the absence of objective measures. Strategic Management Journal 5: 265-273.

Dierickx I, Cool K. 1989. Asset stock accumulation and sustainability of competitive advantage. Management Science 35: 1504-1511.

Fahy J. 1996. Managing culture as a competitive resources: a resource-based view. International Studies in Management and Organization 26: 24-37.

Fisher F, McGowan J, Greewood J. 1983. Folded, Spindled, and Mutilated: Economic Analysis and US v. IBM. MIT Press: Cambridge.

Gabel L. 1984. The micro-foundations of competitive strategy. Working Paper, INSEAD, October.

Grant R. 1991. The resource-base theory of competitive advantage: implication for strategy formulation. California Management Review 33: 114-135.

Grant R. 1997. The knowledge-based view of the firm: implications for management practice. Long Range Planning 30: 450-454.

Grinyer P, McKiernan P, Yasai-Ardekani M. 1988. Market, organizational and managerial correlates of economic performance in the UK electrical engineering industry. Strategic Management Journal 9: $297-318$.
Hall R. 1992. The strategic analysis of intangible resources. Strategic Management Journal 13: $135-144$.

Hall R. 1993. A framework linking intangible resources and capabilities to sustainable competitive advantage. Strategic Management Journal 14: 607-618.

Hambrick DC, Mason PA. 1984. Upper echelons: the organization as a reflection of its top managers. Academy of Management Review 9: 193-206.

Hand J. 1998. Does CEO human capital make a difference? Working Paper. University of North Carolina.

Hansen GS, Wernerfelt B. 1989. Determinants of firm performance: the relative importance of economic and organizational factors. Strategic Management Journal 10: $399-411$.

Harris D, Helfat CE. 1997. Specificity of CEO human capital and compensation. Strategic Management Journal 18: 895-920.

Hirschey M. 1982. Intangible capital aspects of advertising and R\&D expenditures. Journal of Industrial Economics 30: 375-390.

Hunt EB, Marin J, Stone PJ. 1966. Experiments in Induction. Academic Press: New York.

Huselid M. 1999. Human resources, knowledge management and firms' performance. Working Paper. Rutgers University.

IET. Instituto de Estudios Turísticos. 2003. http:// www.iet.tourspain.es [7 march 2003]

INE. Instituto Nacional de Estadística. 2003. http:// www.ine.es [5 February 2003]

Itami H. 1987. Mobilizing Invisible Assets. Harvard University Press: Cambridge.

Jacobson R. 1988. Distinguishing among competing theories of the marketing share effect. Journal of Marketing 52: 68-80.

Jurkovich R. 1974. A core typology of organizational environments. Administrative Science Quarterly 19: 380-394.

Keen PG. 1993. Information technology and the management difference: a fusion map. IBM Systems Journal 32: 17-39.

Kim CW, Chung JY. 1997. Brand popularity, country image and market share: an empirical study. Journal of International Business Studies 28: 361-386.

Lado A, Boyd NG, Wright P. 1992. A competencybased model of sustainable competitive advantage: toward a conceptual integration. Journal of Management 18: 77-91.

Lado A, Willson M. 1994. Human resource system and sustained competitive advantage: competency-based perspective. Academy of Management Review 19: 699-727.

Lenz RT. 1981. Determinants of organizational performance: an interdisciplinary review. Strategic Management Journal 2: 131-154.

Lev B, Zarowin P. 1998. The Boundaries of Financial Reporting and how to extend them. Measuring Intangibles Investment. Economic Co-operation and Development, OCDE.

Levinthal D. 1997. Adaptation on rugged landscapes. Management Science 43: 934-950. 
Liao Z, Greenfield P. 1997. The impact of generic competitive strategies on corporate R\&D: an empirical study in Japan. International Journal of Technology Management 13: 542-553.

Mahoney JT. 1995. The management of resources and the resources of management. Journal of Business Research 33: 91-101.

Maijoor S, Van Witteloostuijn A. 1996. An empirical test of the resource-based theory: strategic regulation in the Duch audit industry. Strategic Management Journal 17: 549-569.

Markides C, Williamson P. 1996. Corporate diversification and organizational structure: a resources based view. Academic of Management Journal 39: 340-367.

Mason E. 1949. The current state of the monopoly problem in the U.S. Harvard Law Review 62: 1265-1285.

Mata FJ, Fuerst WL, Barney JB. 1995. Information technology and sustained competitive advantage: a resource-based analysis. MIS Quarterly 19: 487-505.

Mathis J, Mazier J, Rivaud-Danset D. 1988. La Competitivité Industrielle. Dunod: París.

Michalet CA. 1981. Competitiveness and Internationalisation. Mimeo OCDE: París.

Miller D. 1986. Configurations of strategy and structure: toward a synthesis. Strategic Management Journal 7: 233-249.

Miller D, Friesen PH. 1986. Porter's (1980) generic strategies and performance: an empirical examination with American data. Organization Studies 7: 37-55.

Miller D, Shamsie J. 1996. The resource-based view of the firm in two environments: the Hollywood film studios from 1936 to 1965. Academy of Management Journal 39(3): 519-543.

Montgomery CA, Wernerfelt B. 1989. Diversification, Ricardian rents, and Tobin's q. Rand Journal of Economics 29: 623-632.

Montgomery CA, Wernerfelt B. 1991. Sources of superior performance: market share versus industry effects in the U.S. brewing industry. Management Science 37: 954-958.

Penrose E. 1959. Theory of the Growth of the Firm. Blackwell: Oxford.

Peteraf MA. 1993. The cornerstones of competitive advantage: a resource-based view. Strategic Management Journal 14: 179-191.

Peters TJ, Waterman RH. 1982. In Search of Excellence: Lessons from America's Best-Run Companies. Harper \& Row Publishers: New York.

Porter ME. 1980. Competitive Strategy: Techniques for Analyzing Industries and Competitors. The Free Press: New York.

Porter ME. 1985. Competitive Advantage: Creating and Sustaining Superior Performance. The Free Press: New York.

Porter ME. 2001. Strategy and the internet. Harvard Business Review 79: 62-78.

Powell TC, Dent-Mecallef A. 1997. Information technology as competitive advantage: the role of human, business, and technology resources. Strategic Management Journal 18: 375-405.
Prahalad CK, Hamel G. 1990. The core competence of the corporation. Harvard Business Review 68: 79-91.

Priem RL, Butler JE. 2001. Is the resource-based 'view' a useful perspective for strategic management research? Academy of Management Review 26: 22-40.

Quinlan JR. 1997. See5. www.rulequest.com/See5-info.html [1 September 1999]

Rangone A. 1997. Linking organizational effectiveness, key success factors and performance measures: an analytical framework. Management Accounting Research 8: 207-219.

Reed R, DeFillippi R. 1990. Causal ambiguity, barriers to imitation, and sustainable competitive advantage. Academy of Management Review 15: 88-102.

Rivkin JW. 2000. Imitation of complex strategies. Management Science 46: 824-844.

Rumelt R. 1984. Toward a strategic theory of the firm. In Competitive Strategic Management, Lamb R (ed.). Prentice Hall: New Jersey; 556-570.

Rumelt R. 1991. How much does industry matter? Strategic Management Journal 12: 167-185.

Rumelt R, Wensley R. 1980. In search of the market share effect. Working Paper. University of California.

Russell LC. 1990. How to value covenants not to compete. Journal of Accountancy 170: 85-92.

Schendel D, Hofer CW. 1979. Strategic Management: A New View of Business Policy and Planning. Little Brown: Boston.

Schmalensee R. 1985. Do markets differ much? American Economic Review 75: 341-351.

Schmalensee R. 1987. Collusion versus differential efficiency: testing alternative hypotheses. Journal of Industrial Economics 35: 399-425.

Schwenk CR. 1984. Cognitive simplification processes in strategic decision-making. Strategic Management Journal 5: 11-128.

Siggelkow N. 2001. Change in the presence of fit: the rise, the fall, and the renaissance of Liz Claiborne. Academy of Management Journal 44: 838-857.

Smiddy P. 1983. Brands. An asset to be ignored? Accountancy 94: 95-96.

Smith KG, Guthrie JP, Chen MJ. 1989. Strategy, size and performance. Organization Studies 10: 63-81.

Teece DJ. 1998. Capturing value from knowledge assets: the new economy, markets for know-how, and intangible assets. California Management Review 40: 55-79

Teece DJ, Rumelt R, Dosi G, Winter S. 1994. Understanding corporate coherence: theory and evidence. Journal of Economic Behavior and Organization 23: $1-30$.

Truss C, Gratton T. 1994. Strategic human resource management: a conceptual approach. The International Journal of Human Resource Management 5: 664-703.

Tushman ML, Romanelli E. 1985. Organizational evolution: a metamorphosis model of convergence and reorientation. In Research in Organizational Behavior, Cummings LL, Staw BM (eds). JAI Press: Greenwich CT; 171-222.

Ulrich D, Lake D. 1990. Organizational Capability: Competing from the Inside/Out. Wiley: New York. 
Venkatraman N, Ramanujam V. 1986. Measurement of business performance in strategy research: a comparison of approaches. Academy of Management Review 11: $801-814$.

Vickery G. 1999. Intangibles and Competitiveness: An Empirical Approach. Edward Elgar Publishing: London.

Wallman S. 1995. The future of accounting and disclosure in an evolving world: the need form dramatic change. Accounting Horizons 9: 81-91.

Wallman S. 1996. The future of accounting and financial reporting. Part II: the colorized approach. Accounting Horizons 10: 138-148.

Wernerfelt B. 1984. A resource-based view of the firm. Strategic Management Journal 5: 171-180.

Wesley F, Mintzberg H. 1989. Visionary leadership and strategic management. Strategic Management Journal 10: $17-32$.

White R. 1986. Generic business strategies, organizational context and performance: an empirical investigation. Strategic Management Journal 7: 217-231.
White R, Hamermesh, RG. 1981. Toward a model of business unit performance: an integrative approach. Academy of Management Review 6: 213-223.

Wright PM, McMahan GC, McWilliams A. 1994. Human resources and sustained competitive advantage: a resource-based perspective. The International Journal of Human Resource Management 5: 301-326.

WTO. World Tourism Organization. 2003. http:// www.world-tourism.org [7 march 2003]

Young A. 1998. Towards an Interim Statistical Framework: Selecting the Core Components of Intangible Investment. Measuring Intangibles Investment. Economic Co-operation and Development, OCDE.

Zadeth LA. 1965. Fuzzy sets. Information and Control 8: 338-353.

Zimmer AC. 1983. Verbal versus numerical processing of subjective probabilities. In Decision-Making Under Uncertainty, Scholz RW (ed.). Elsevier: Amsterdam; 159-182. 